\title{
FAKTOR-FAKTOR YANG MEMPENGARUHI PENURUNAN INTENSITAS KUNJUNGAN WISATAWAN DI DAYA TARIK WISATA CANDIDASA, KABUPATEN KARANGASEM, BALI
}

\author{
Ida Ayu Dyana Prawerti \\ I GPB. Sasrawan Mananda \\ Luh Gede Leli Kusuma Dewi \\ Email : prawerti@gmail.com \\ PS. S1 Industri Perjalanan Wisata \\ Fakultas Pariwisata UNUD
}

\begin{abstract}
ABSTRAK
Daya Tarik Wisata Candidasa memiliki keindahan alam serta atraksi wisata yang cukup menarik. Selama tujuh tahun terakhir intensitas kunjungan wisatawan di Daya Tarik Wisata Candidasa mengalami penurunan. Kunjungan tertinggi pada tahun 2010 yakni mencapai 7473 wisatawan, namun pada tahuntahun berikutnya mengalami penurunan yaitu pada tahun 2011, tahun 2012 dan tahun 2014 dengan ratarata pertumbuhan sebesar $-0,50 \%$. Berdasarkan hal tersebut maka perlu untuk dikaji (1) faktor yang mempengaruhi penurunan intensitas kunjungan wisatawan Daya Tarik Wisata Candidasa; (2) faktor dominan yang mempengaruhi penurunan intensitas kunjungan wisatawan di Daya Tarik Wisata Candidasa. Teknik pengumpulan data yang digunakan adalah observasi, wawancara, kuesioner, dokumentasi dan studi kepustakaan. Sampel yang digunakan sebanyak 100 wisatawan yang sedang berkunjung ke Daya Tarik Wisata Candidasa yang dipilih secara accidental sampling. Teknik analisis data yang digunakan adalah analisis faktor. Hasil analisis faktor menunjukkan dari 27 variabel dapat direduksi menjadi 22 variabel. Terdapat 5 (lima) variabel dikeluarkan dari model karena tidak memenuhi kriteria MSA > 0,5 yaitu variabel kelayakan infrastruktur (X4), jarak (X5), ketersediaan tourist information center (X9), politik global (X19) dan ekonomi nasional (X13). Hasil analisis faktor menunjukkan bahwa terbentuk 8 (delapan) faktor yang merupakan faktor-faktor yang mempengaruhi penurunan intensitas kunjungan wisatawan di Daya Tarik Wisata Candidasa, diantaranya faktor atraksi dengan eigenvalue 8,171, faktor keamanan dengan eigenvalue 2,665, faktor kualitas dengan eigenvalue 1,983, faktor politik dengan eigenvalue 1,622, faktor teknologi dengan eigenvalue 1,560, faktor amenitas dengan eigenvalue 1,375, faktor promosi dengan eigenvalue 1,099 dan faktor efisiensi waktu dengan eigenvalue 1,047. Dari hasil analisis faktor diketahui bahwa faktor dominan yang mempengaruhi penurunan intensitas kunjungan wisatawan di Daya Tarik Wisata Candidasa adalah faktor atraksi karena memiliki eigenvalue tertinggi diantara faktor lain yang terbentuk. Adapun variabel yang termasuk dalam faktor atraksi adalah kondisi daya tarik wisata, kebersihan daya tarik wisata, kenyamanan wisatawan, kondisi/isu kesehatan, peran masyarakat lokal dan aktifitas wisata.
\end{abstract}

Kata kunci : Kunjungan Wisatawan, Daya Tarik Wisata Candidasa.

\section{PENDAHULUAN}

Daya Tarik Wisata Candidasa tergolong daya tarik wisata tirta atau wisata bahari yang didukung sejumlah fasilitas akomodasi seperti hotel dan restoran. Jenis-jenis aktivitas wisata dapat dilakukan wisatawan antara lain berenang, bermain kano, snorkeling, memancing, trekking melalui perbukitan, serta berlayar menyaksikan keindahan gugusan pulau-pulau kecil yang dapat dijangkau dengan menggunakan perahu nelayan. Dengan berbagai macam keindahan serta atraksi wisata yang ditawarkan, hal tersebut menjadikan Daya Tarik Wisata Candidasa sebagai daya tarik 
wisata yang cukup popular baik di kalangan wisatawan nusantara maupun mancanegara. Berdasarkan data statistik Dinas Kebudayaan dan Pariwisata Kabupaten Karangasem kunjungan wisatawan ke Daya Tarik Wisata Candidasa dari tahun 2008 sampai tahun 2014 cenderung mengalami penurunan. Kunjungan tertinggi terjadi pada tahun 2010, yakni mencapai 7.473 wisatawan, namun pada tahuntahun berikutnya kunjungan wisatawan mengalami penurunan yang cukup drastis, yakni 1886 wisatawan (tahun 2011), 332 wisatawan (tahun 2012). Pada tahun 2013 kunjungan wisatawan ke Daya Tarik Wisata Candidasa menunjukkan peningkatan, yakni mencapai 1.667 wisatawan, namun pada tahun berikutnya (2014) kembali mengalami penurunan, yakni 1.411 wisatawan.

Menurut Butler dalam Pitana (2005) terdapat 7 (tujuh) fase pengembangan pariwisata atau siklus hidup pariwisata (Destination Area Lifecycle). Saat ini siklus hidup pariwisata Daya Tarik Wisata Candidasa berada pada fase decline. Berdasarkan perbandingan jumlah kunjungan wisatawan dan pendapatan retribusi pada 4 (empat) daya tarik wisata tirta atau wisata bahari yang ada di Kabupaten Karangasem Tahun 2013-2014, diketahui bahwa Daya Tarik Wisata Candidasa merupakan yang paling rendah dibandingkan dengan Padangbai, Jemeluk, Tulamben. Terdapat 4 (empat) buah penginapan yang saat ini beralih fungsi menjadi rumah kost diantaranya adalah penginapan Lila Barata, Segarawangi, Ayodya dan Ratna, beberapa juga restoran sudah tidak beroperasi lagi. Penurunan kunjungan wisatawan juga diakui oleh para pelaku wisata seperti penyedia jasa penginapan di sekitar Daya Tarik Wisata Candidasa yang menuturkan bahwa beberapa tahun terakhir hunian kamar mulai mengalami penurunan. Pedagang yang sehari-hari berjualan di art shop dan kios-kios sepanjang pantai mengeluhkan bahwa pendapatan yang diperoleh dari hasil penjualan saat ini cenderung menurun. Wisatawan yang datang untuk berjemur atau yang ingin melakukan aktivitas wisata lainnya di sekitar pantai sudah jarang.

Berdasarkan latar belakang tersebut maka merupakan suatu fenomena yang menarik dan relevan untuk dikaji yaitu (1) faktor yang mempengaruhi penurunan intensitas kunjungan wisatawan di Daya Tarik Wisata Candidasa; (2) faktor dominan yang mempengaruhi penurunan intensitas kunjungan wisatawan di Daya Tarik Wisata Candidasa.

\section{METODE}

Penelitian ini dilakukan di Daya Tarik Wisata Candidasa, Kabupaten Karangasem. Variabel yang diteliti merupakan penerapan dari konsep Cooper (1993) yaitu komponen suatu daya tarik wisata, terdapat 27 variabel yang diteliti meliputi kondisi daya tarik wisata (X1), aktifitas wisata (X2), kebersihan daya tarik wisata (X3), kelayakan infrastruktur (X4), jarak (X5), efisiensi waktu (X6), ketersediaan sarana dan prasarana (X7), kelayakan sarana dan prasarana (X8), ketersediaan tourist information center (X9), keamanan pengunjung (X10), keamanan daya tarik wisata (X11), keramahtamahan penduduk lokal (X12), keramahtamahan pelaku wisata (X13), kuantitas promosi (X14), harga produk wisata (X15), kesesuaian harga dengan kualitas produk wisata (X16), pelayanan pelaku wisata (X17), kenyamanan wisatawan (X18), politik global (X19), politik nasional (X20), ekonomi global (X21), ekonomi nasional (X22), peran masyarakat lokal (X23), kondisi/isu kesehatan (X24), sistem teknologi informasi (X25), akses telekomunikasi (X26) dan daya saing daya tarik wisata sejenis (X27).

Sampel yang digunakan merupakan wisatawan yang sedang berkunjung ke Daya Tarik Wisata Candidasa yang dipilih secara accidental sampling dengan jumlah sampel sebanyak 100 (Gudono : 2015). Teknik analisis data dalam penelitian ini adalah analisis data kuantitatif, data kuantitatif diperoleh melalui penyebaran kuesioner dengan menggunakan skala likert, kemudian dianalisis dengan menggunakan analisis faktor dengan bantuan program SPSS for Windows 17.0. Tahap-tahap analisis data meliputi Uji Validitas, Uji Reliabilitas, Merumuskan masalah, Membuat matriks korelasi, Menentukan Jumlah Faktor, Rotasi Faktor, Interpretasi Faktor dan Uji Ketepatan Model. 


\section{PEMBAHASAN}

\section{Uji Validitas}

Berdasarkan hasil uji validitas setiap variabel memiliki koefisien korelasi Pearson Product Moment > 0,367 hal ini menunjukkan bahwa seluruh pernyataan pada kuisioner adalah valid.

\section{Uji Reliabilitas}

Berdasarkan hasil uji reliabilitas diketahui bahwa Cronbach's Alpha $(\alpha)>0,6$ yaitu sebesar 0,944 , hal ini menunjukkan bahwa instrumen penelitian adalah reliable.

\section{Analisis Faktor}

Data yang diperoleh melalui penyebaran kuesioner, kemudian dianalisis dengan menggunakan SPSS for Windows 17.0. Menurut Suliyanto (2005), tahapan analisis faktor yaitu sebagai berikut :

\section{Merumuskan Masalah}

Melalui analisis faktor, maka dapat diketahui faktor-faktor yang mempengaruhi penurunan intensitas kunjungan wisatawan di Daya Tarik Wisata Candidasa diidentifikasi dari 27 variabel. Sampel yang digunakan merupakan wisatawan yang berkunjung ke Daya Tarik Wisata Candidasa yang berjumlah 100 yang dipilih secara accidental.

\section{Membuat Matriks Korelasi}

Pada matriks korelasi dapat diidentifikasikan bahwa hasil uji nilai Bartlett Test of Sphericity yang diperoleh adalah 1523,273 dengan signifikansi 0,000, ini menunjukkan bahwa antar variabel terjadi korelasi sehingga model faktor dapat digunakan. Hasil uji nilai KMO adalah 0,757, ini menunjukkan bahwa pengambilan sampel cukup memadai dalam matrik korelasi karena KMO di atas 0,5. Hasil uji MSA yang diperoleh bahwa 27 variabel yang di uji telah memenuhi kriteria karena nilai MSA masingmasing variabel $>0,5$ sehingga seluruh variabel dapat diproses ke tahap berikutnya.

3. Menentukan Jumlah Faktor

Penentuan jumlah faktor dilakukan untuk menentukan berapa banyak faktor yang terbentuk. Faktor-faktor yang dipilih adalah faktor yang mempunyai eigenvalue $\geq 1$.
Tabel 1

Total Variance Explained

\begin{tabular}{|l|r|r|r|}
\hline \multirow{2}{*}{$\begin{array}{c}\text { Compone } \\
\text { nt }\end{array}$} & \multicolumn{3}{|c|}{ Initial Eigenvalues } \\
\cline { 2 - 4 } & Total & \% of Variance & $\begin{array}{c}\text { Comulative } \\
\text { \% }\end{array}$ \\
\hline X1 & $\mathbf{8 , 1 7 1}$ & $\mathbf{3 0 , 2 6 3}$ & $\mathbf{3 0 , 2 6 3}$ \\
\hline X2 & $\mathbf{2 , 6 6 5}$ & $\mathbf{9 , 8 7 0}$ & $\mathbf{4 0 , 1 3 4}$ \\
\hline X3 & $\mathbf{1 , 9 8 3}$ & $\mathbf{7 , 3 4 5}$ & $\mathbf{4 7 , 4 7 9}$ \\
\hline X4 & $\mathbf{1 , 6 2 2}$ & $\mathbf{6 , 0 0 6}$ & $\mathbf{5 3 , 4 8 4}$ \\
\hline X5 & $\mathbf{1 , 5 6 0}$ & $\mathbf{5 , 7 7 6}$ & $\mathbf{5 9 , 2 6 1}$ \\
\hline X6 & $\mathbf{1 , 3 7 5}$ & $\mathbf{5 , 0 9 2}$ & $\mathbf{6 4 , 3 5 3}$ \\
\hline X7 & $\mathbf{1 , 0 9 9}$ & $\mathbf{4 , 0 6 9}$ & $\mathbf{6 8 , 4 2 2}$ \\
\hline X8 & $\mathbf{1 , 0 4 7}$ & $\mathbf{3 , 8 7 8}$ & $\mathbf{7 2 , 3 0 0}$ \\
\hline X9 & 0,881 & 3,263 & 75,563 \\
\hline X10 & 0,797 & 2,954 & 78,516 \\
\hline X11 & 0,722 & 2,676 & 81,192 \\
\hline X12 & 0,677 & 2,507 & 83,699 \\
\hline X13 & 0,570 & 2,113 & 85,812 \\
\hline X14 & 0,521 & 1,928 & 87,740 \\
\hline X15 & 0,500 & 1,851 & 89,591 \\
\hline X16 & 0,460 & 1,703 & 91,293 \\
\hline X17 & 0,435 & 1,610 & 92,904 \\
\hline X18 & 0,332 & 1,231 & 94,134 \\
\hline X19 & 0,302 & 1,120 & 95,255 \\
\hline X20 & 0,268 & 0,991 & 96,246 \\
\hline X21 & 0,229 & 0,848 & 97,094 \\
\hline X22 & 0,212 & 0,786 & 97,880 \\
\hline X23 & 0,154 & 0,570 & 98,449 \\
\hline X24 & 0,129 & 0,477 & 98,927 \\
\hline X25 & 0,116 & 0,429 & 99,355 \\
\hline X26 & 0,106 & 0,392 & 99,748 \\
\hline X27 & 0,068 & 0,252 & 100,000 \\
\hline Sumb & & & \\
\hline
\end{tabular}

Sumber: Hasil Penelitian, 2015

Berdasarkan Tabel 1, teridentifikasi bahwa terdapat sebanyak 8 (delapan) faktor terbentuk dengan nilai eigenvalue $\geq 1$ yaitu 8,$171 ; 2,665$; 1,$983 ; 1,622 ; 1,560 ; 1,375 ; 1,099 ; 1,047$.

4. Rotasi Faktor

Rotasi faktor digunakan untuk menyederhanakan matrik faktor. Berdasarkan hasil rotasi, maka didapatkan dari 27 variabel yang dirotasi, terdapat sebanyak 5 (lima) variabel yang tidak memenuhi kriteria karena tidak melewati factor loading $>0,5$, diantaranya kelayakan infrastruktur (X4), jarak (X5), ketersediaan tourist information center (X9), politik global (X19) dan ekonomi nasional (X22), sedangkan variabel yang memenuhi syarat sebanyak 22 variabel yang tersebar ke dalam 8 (delapan) faktor yang merupakan faktor-faktor yang mempengaruhi penurunan intensitas kunjungan wisatawan di Daya Tarik Wisata Candidasa, kabupaten Karangasem, Bali. 5. Interpretasi Faktor 
Pada tahap ini terdapat 5 (lima) variabel yang dikeluarkan atau dieliminasi karena tidak memenuhi factor loading $>0,5$ yaitu kelayakan infrastruktur (X4), jarak (X5), ketersediaan tourist information center (X9), politik global (X19) dan ekonomi nasional (X22) dan terdapat 22 variabel yang memenuhi factor loading $>0,5$ yang tersebar ke dalam 8 (delapan) faktor. Pada tahap ini juga dilakukan pemberian nama terhadap faktor yang terbentuk. Berikut penamaan faktor sesuai dengan variabel yang membentuk :

1) Faktor atraksi (attraction) yaitu kondisi daya tarik wisata, kebersihan daya tarik wisata, aktivitas wisata, kenyamanan wisatawan, kondisi/isu kesehatan dan peran masyarakat lokal.

2) Faktor keamanan yaitu keamanan daya tarik wisata, keamanan pengunjung, keramahtamahan pelaku wisata dan keramahtamahan masyarakat lokal.

3) Faktor harga yaitu kesesuaian harga dengan kualitas produk dan kualitas pelayanan.

4) Faktor politik yaitu politik nasional dan daya saing daya tarik wisata sejenis.

5) Faktor teknologi yaitu sarana teknologi dan informasi dan akses telekomunikasi.

6) Faktor amenitas (amenities) yaitu : kelayakan sarana dan prasarana dan ketersediaan sarana dan prasarana.

7) Faktor promosi yaitu kuantitas promosi dan harga produk wisata yang normal.

8) Faktor efisiensi waktu yaitu efisiensi waktu dan ekonomi global.

\section{Uji Ketepatan Model}

Model faktor perlu diuji ketepatannya untuk mengetahui apakah model mampu menjelaskan dengan akurat. Dasar pengujiannya adalah dengan melihat persentase jumlah residual yaitu perbedaan antara nilai korelasi awal dengan korelasi hasil reproduced berdasarkan hasil estimasi matriks faktor, menunjukan bahwa persentase residual adalah $28 \%$ dengan nilai absolute $>0.05$. Hal ini mengidentifikasikan bahwa model dalam penelitian ini memiliki ketepatan sebesar $72 \%$ dengan tingkat kesalahan $5 \%$.

\section{A. Faktor-Faktor yang Mempengaruhi Penurunan Intensitas Kunjungan Wisatawan di Daya Tarik Wisata Candidasa}

Berdasarkan 6 (enam) tahap analisis faktor, maka diperoleh hasil 8 (delapan) faktor yang mempengaruhi penurunan intensitas kunjungan wisatawan di Daya Tarik Wisata Candidasa. Adapun uraian 8 (delapan) faktor sebagai berikut

1. Faktor atraksi, dengan eigenvalue sebesar 8,171 dan tingkat kemampuan menjelaskan keragaman dari variabel yang ada dalam data sebesar 30,263\%, terdiri dari 6 (enam) variabel yaitu (1) Kondisi daya tarik wisata, ini mengacu pada kondisi fisik Daya Tarik Wisata Candidasa yang mengalami kerusakan dan tidak menarik lagi bagi wisatawan (2) Kebersihan daya tarik wisata, ini mengacu pada kurang terjaminnya kebersihan lokasi daya tarik wisata dan sekitarnya. (3) Kenyamanan wisatawan, ini mengacu pada kurangnya rasa nyaman yang dirasakan wisatawan selama berwisata (4) Kondisi/isu kesehatan, ini mengacu pada ancaman penularan virus penyakit seperti Rabies, Mers, Sars, Flu Burung/H5N1 dan lain-lain mengingat semenjak Pulau Bali dinyatakan terjangkit rabies dan ditetapkan sebagai kawasan karantina penyakit anjing gila, yang dikuatkan dengan Peratuan Menteri Pertanian Nomor 1696 Tahun 2008. Dari data dan kajian analisis Dinas Pariwisata Provinsi Bali, bahwa memang ada dampak dari rabies, yaitu adanya ketakutan dari wisatawan yang mendengar isu tentang korban rabies yang cukup tinggi di Bali. (5) Peran masyarakat lokal, ini mengacu pada kurang aktifnya masyarakat lokal terlibat dalam kegiatan pariwisata. (6) Aktivitas wisata, mengacu pada terbatasnya aktivitas wisata yang dapat dilakukan wisatawan.

2. Faktor keamanan, dengan eigenvalue sebesar 2,665 dan tingkat kemampuan menjelaskan keragaman dari variabel yang ada dalam data sebesar $9,870 \%$, terdiri dari 4 (empat) variabel, yaitu (1) Keamanan daya tarik wisata, ini mengacu pada kurang amannya lingkungan daya tarik wisata untuk dikunjungi. (2) Keamanan wisatawan ini 
mengacu pada kurangnya rasa aman yang dirasakan wisatawan selama berwisata. (3) Keramahtamahan pelaku wisata, ini mengacu pada sikap pelaku wisata yang kurang ramah terhadap wisatawan. (4) Keramahtamahan masyarakat lokal, ini mengacu pada sikap masyarakat lokal yang kurang ramah terhadap wisatawan.

3. Faktor harga, dengan eigenvalue sebesar 1,983 dan tingkat kemampuan menjelaskan keragaman dari variabel yang ada dalam data sebesar $7,345 \%$, terdiri dari 2 (dua) variabel, yaitu (1) Kesesuaian harga dengan kualitas produk, ini mengacu pada kurang sesuainya harga produk wisata yang ditawarkan wisatawan dengan kualitas produk yang didapatkan. (2) Kualitas pelayanan, ini mengacu pada kurangnya kualitas pelayanan yang diberikan pelaku wisata kepada wisatawan.

4. Faktor politik, dengan eigenvalue sebesar 1,622 tingkat kemampuan menjelaskan keragaman dari variabel yang ada dalam data sebesar $6,006 \%$, terdiri dari 2 (dua) variabel, yaitu (1) Politik nasional, ini mengacu pada kondisi politik nasional negara Indonesia. Kondisi politik yang sedang memanas dan tidak terkendali akan menyebabkan permintaan pariwisata turun secara drastis, disamping itu wisatawan akan merasa tidak aman untuk melakukan perjalanan dan secara langsung hal ini akan berpengaruh pada penurunan intensitas kunjungan wisatawan, (2) Daya saing daya tarik wisata sejenis, ini mengacu pada mulai dikenalnya daya tarik wisata sejenis yang dianggap lebih menarik.

5. Faktor teknologi dengan eigenvalue sebesar 1,560 dan tingkat kemampuan menjelaskan keragaman dari variabel yang ada dalam data sebesar 5,776\%, terdiri dari 2 (dua) variabel, yaitu (1) Sarana teknologi dan informasi, ini mengacu pada kurang memadainya sarana teknologi dan informasi seperti e-banking, hotels reservation dan lain-lain. (2) Akses telekomunikasi, ini mengacu pada terhambatnya akses komunikasi di sekitar daya tarik wisata Candidasa.

6. Faktor amenitas (amenities), dengan eigenvalue sebesar 1,375 dan tingkat kemampuan menjelaskan keragaman dari variabel yang ada dalam data sebesar $5,092 \%$, terdiri dari 2 (dua) variabel yaitu (1) Kelayakan sarana dan prasarana, ini mengacu pada kurang layaknya sarana dan prasarana yang ada di Daya Tarik Wisata Candidasa. (2) Ketersediaan sarana dan prasarana, ini mengacu pada masih terbatasnya sarana dan prasarana dalam memenuhi kebutuhan wisatawan.

7. Faktor promosi, dengan eigenvalue sebesar 1,099 dan tingkat kemampuan menjelaskan keragaman dari variabel yang ada dalam data sebesar 4,069\%, terdiri dari 2 (dua) variabel, yaitu (1) Kuantitas promosi, ini mengacu pada kurangnya promosi mengenai Daya Tarik Wisatawa Candidasa kepada wisatawan. (2) Harga produk wisata yang normal, ini mengacu pada produk wisata yang ditawarkan di Daya Tarik Wisata Candidasa cenderung mahal bagi wisatawan.

8. Faktor efisiensi waktu, dengan eigenvalue sebesar 1,047 dan tingkat kemampuan menjelaskan keragaman dari variabel yang ada dalam data sebesar 3,878\%, terdiri dari 2 (dua) variabel yaitu (1) Efisiensi waktu, ini mengacu bahwa wisatawan yang menuju Daya Tarik Wisata Candidasa menghabiskan waktu tempuh yang lama. (2) Ekonomi global, kondisi ekonomi global yang tidak stabil akan berimbas pada kenaikan hargaharga setiap produk, salah satunya produk wisata yang juga berpengaruh terhadap pengeluaran wisatawan.

\section{B. Faktor dominan yang Mempengaruhi Penurunan Intensitas Kunjungan Wisatawan di Daya Tarik Wisata Candidasa}

Berdasarkan hasil penelitian maka yang menjadi faktor dominan adalah faktor atraksi dengan eigenvalue tertinggi yaitu sebesar 8,171, yang terdiri 6 (enam) variabel diantaranya variabel kondisi daya tarik wisata, kebersihan lingkungan daya tarik wisata, keanekaragaman aktivitas wisata yang dapat dilakukan, kenyamanan wisatawan berwisata, kondisi/isu kesehatan dan peran masyarakat lokal.

Hasil analisis faktor ini diperkuat dengan hasil wawancara kepada 10 informan. Seluruh informan menyatakan bahwa faktor dominan 
yang mempengaruhi penurunan intensitas kunjungan wisatawan di Daya Tarik Wisata adalah faktor atraksi. Kondisi fisik Daya Tarik Wisata Candidasa yang mengalami dan dianggap sudah tidak menarik, hal ini dikarenakan terdapat penghalang berupa kribkrib pantai sebagai penahan abrasi yang cukup parah sehingga mengakibatkan aktivitas wisata yang dapat dilakukan oleh wisatawan menjadi terbatas dikarenakan terhalang oleh krib-krib dan jalan beton. Pasir pantai juga menjadi penyebab kondisi daya tarik tidak lagi semenarik dahulu. Pasir pantai yang awalnya sebagai salah satu unsur yang menambah keindahan saat ini jumlahnya semakin berkurang akibat tergerus abrasi pantai. Kebersihan di sekitar Daya Tarik Wisata Candidasa yang masih sangat kurang

\section{SIMPULAN DAN SARAN}

Berdasarkan hasil analisis dan pembahasan mengenai faktor-faktor yang mempengaruhi penurunan intensitas kunjungan wisatawan di Daya Tarik Wisata Candidasa maka didapatkan simpulan sebagai berikut :

1. Faktor-faktor yang mempengaruhi penurunan intensitas kunjungan wisatawan di Daya Tarik Wisata Candidasa antara lain

a) Faktor atraksi terdiri dari 6 (enam) variabel yaitu kondisi daya tarik wisata kebersihan daya tarik wisata, aktivitas wisata, kenyamanan wisatawan, dan kondisi/isu kesehatan dan peran masyarakat lokal.

b) Faktor keamanan terdiri dari 4 (empat) variabel yaitu keamanan daya tarik wisata, keamanan pengunjung, keramahtamahan pelaku wisata dan keramahtamahan masyarakat lokal.

c) Faktor kualitas terdiri dari 2 (dua) variabel yaitu kesesuaian harga dengan kualitas produk dan kualitas pelayanan.

d) Faktor politik terdiri dari 2 (dua) variabel yaitu politik nasional dan daya saing daya tarik wisata sejenis.

e) Faktor teknologi terdiri dari 2 (dua) variabel yaitu sarana teknologi dan informasi dan akses telekomunikasi.

f) Faktor fasilitas (amenities) terdiri dari 2 (dua) variabel yaitu kelayakan sarana dan prasarana dan ketersediaan sarana dan prasarana.

g) Faktor promosi terdiri dari 2 (dua) variabel yaitu : kuantitas promosi dan harga produk wisata yang normal.

h) Faktor efisiensi waktu terdiri dari 2 (dua) variabel yaitu : efisiensi waktu dan ekonomi global.

2. Faktor dominan yang mempengaruhi yang Mempengaruhi Penurunan intensitas Kunjungan Wisatawan di Daya Tarik Wisata Candidasa adalah faktor atraksi dengan eigenvalue tertinggi yaitu sebesar 8,171 .

Adapun saran yang dapat diberikan adalah:

1. Melakukan penanganan dan pemeliharaan secara optimal dan berkelanjutan, penanganan dan pemeliharaan tersebut diharapkan terlaksana tanpa mengganggu kegiatan kepariwisataan. Selain itu, perlu diadakannya penciptaan atraksi wisata/produk baru, dengan memanfaatkan potensi-potensi yang ada.

2. Kepada para pemangku kepentingan seperti pemerintah Kabupaten Karangasem untuk segera mengatasi permasalahan kunjungan wisatawan dengan memperhatikan 8 (delapan) faktor tersebut guna meningkatkan kembali kunjungan wisatawan.

\section{DAFTAR PUSTAKA}

Cooper, Chris, et al. 1993. Tourism : Principles \& Practice. London : Pitman Publishing

Dinas Kebudayaan dan Pariwisata Kabupaten Karangasem. 2015. Data Jumlah Kunjungan Wisatawan dan Pendapatan Retribusi Wisata Bahari Kabupaten Karangasem.

Gudono. 2015. Analisis Data Multivariat. Yogyakarta : BPFE

Pitana, I Gede dan Putu Gayatri. 2005. Sosiologi Pariwisata. Yogyakarta : CV Andi Offset.

Suliyanto. 2005. Analisis Data Dalam Aplikasi Pemasaran. Bogor : Ghalia. 